各種耐食性非鉄金属材料の選定指針†

2. 銅ならびに銅合金

川辺允志*鈴木 忍**

Guidelines for The Selection of Corrosive-Resistant Non-Ferrous Metals

II: Copper and Copper Alloy

by

Atsushi KAWABE* and Shinobu SUZUKI**

Key words:Copper,Copper alloy,Corrosion, Corrosion prevention

1 はじめに

銅は人間にとっての必須元素の一つであるが、 我々の生活をはじめ産業や工業にとっても重要な 金属であり、その利用は多岐にわたるが、紙数が 限られているので、分野を限って記述する.

\section{2 給水・給湯用配管}

銅管は耐食性，施工性に優れていることから。 給水・給湯用配管として多く使用されている。 しかしながら, 使用環境, 特に水質の影響に より，管内面からの腐食により漏洩事故を引 き起こすことがある。銅管を給水・給湯用配 管として用いた場合に経験される管内面から の腐食は, 青水, 孔食, 潰食に大別され, 表 1 にそれらを管内流体, 配管システム, 腐食要 因とともにまとめた結果を示す。給水・給湯 用配管として用いた銅管では, 腐食以外に疲
労割れも発生することがあり，これも含め， それぞれの特徵, 発生要因および対策を以下 に示す。

\section{$2 \cdot 1$ 青水}

銅管の管内には通水とともに亜酸化銅，通湯 によってはさらに酸化銅, 塩基性炭酸銅や才 ルトケイ酸銅が形成されて水中への銅イオン の溶出量も低くなる. しかしながら, 水の $\mathrm{pH}$ が低い場合には先の化合物による皮膜が安定 して形成されず，継続して銅イオンが溶出す ることがある。その場合，銅イオン溶出量が 水道水の水質基準の $1 \mathrm{ppm}$ 以下（同濃度の水は 青くない) であっても, 石賖や皮脂の脂肪酸 と結合して青系色の銅石鹸を形成し，これが バスタブや洗面台の喫水面付近に付着してい わゆる「青水」問題が発生する。著者らの調

表1 給水·給湯用銅管の腐食分類と発生要因

\begin{tabular}{|c|c|c|c|c|c|c|}
\hline \multicolumn{2}{|c|}{ 腐食現象 } & 青水 & \multicolumn{3}{|c|}{ 孔食 } & 潰食 \\
\hline \multirow{2}{*}{\multicolumn{2}{|c|}{ 分 類 }} & \multirow{2}{*}{-} & \multirow{2}{*}{$\begin{array}{c}\mathrm{I} \text { 型 } \\
\text { (冷水型) }\end{array}$} & \multicolumn{2}{|r|}{ II型 } & \multirow{2}{*}{-} \\
\hline & & & & II型 & マウンドレス型 & \\
\hline \multicolumn{2}{|c|}{ 管内流体 } & 上水, 地下水 & 地下水 & \multicolumn{2}{|r|}{ 上水 } & 上水 \\
\hline \multicolumn{2}{|c|}{$\begin{array}{c}\text { 配管システ } \\
\text { ム }\end{array}$} & $\begin{array}{c}\text { 一過式, } \\
\text { 強制循環式 }\end{array}$ & 一過式 & 強制循環式 & 一過式 & 強制循環式 \\
\hline \multirow{2}{*}{$\begin{array}{l}\text { 要 } \\
\text { 因 }\end{array}$} & $\begin{array}{l}\text { 環 } \\
\text { 境 }\end{array}$ & $\begin{array}{c}\text { 低 } \mathrm{pH} \\
\text { 例えば, } 6.5 \text { 以下 }\end{array}$ & 遊離炭酸 $15 \mathrm{ppm}$ 以上 & $\begin{array}{c}\mathrm{SO}_{4}^{2-} / \mathrm{HCO}_{3}^{-}>1, \\
\text { 高残留塩素, } \\
\text { 低流速 }\end{array}$ & $\begin{array}{c}\text { 高 } \mathrm{SiO}_{2}(20 \mathrm{ppm} \text { 以上 }) \text {, } \\
\mathrm{SO}_{4}{ }^{2-} / \mathrm{HCO}_{3}{ }^{-}>0.5 \\
\text { ※典型的な条件 }\end{array}$ & $\begin{array}{c}\text { 溶存空気, } \\
\text { 高流速, } \\
\text { 低 } \mathrm{pH}\end{array}$ \\
\hline & $\begin{array}{l}\text { 材 } \\
\text { 料 }\end{array}$ & $\begin{array}{l}\text { 硬質, 軟質銅管 } \\
\text { に無関係 }\end{array}$ & $\begin{array}{c}\text { 軟質銅管: カーボン皮 } \\
\text { 膜 }\end{array}$ & \multicolumn{2}{|c|}{ 硬質, 軟質銅管に無関係 } & $\begin{array}{c}\text { 硬質, 軟質 } \\
\text { 銅管に無関 } \\
\text { 係 }\end{array}$ \\
\hline
\end{tabular}

$\dagger$ 原稿受理 平成 26 年 2 月 28 日 Received Feb.28,2014 C2014 The Society of Materials Science,Japan

* (株) 関西テクノカンパニー テ590-0105 堺市竹城台,Kansai Techno Co.,Takesirodai,Sakai,590-0105

** (株) UACJ ₹455-8670 名古屋市港区千年,UACJ Co., Minami-ku, Nagoya,455-8670 
査によれば, 青水が発生する場合の $\mathrm{pH}$ は 7 以下の場合 が多く, 特に 6.5 以下の場合には酸化皮膜が安定して形 成されないため, 銅イオンの溶出量は多くなると考えて いる．対策としてはアルカリ性化合物を添加して pHを 上昇させることが有効とされているが ${ }^{1)}$, 薬品処理によ る対策は設備上の理由により，適用には限界があること もあり，その場合には銅管内面に純スズを被覆した STC 銅管の使用が効果的である。同材料では，銅管使用時の 銅イオン溶出量が $1 \mathrm{ppm}$ となる水を使用しても，同值を $0.1 \mathrm{ppm}$ 以下に抑えることができ, 材料による青水対策が 可能となる ${ }^{2)}$. また，青水対策用内面スズ被覆銅管（C Lシャット）も同様に青水対策として有効である.

\section{$2 \cdot 2$ 孔食}

(1) I 型孔食

I 型孔食は，一過式給水・給湯配管用の軟質銅管およ び給湯器用熱交換器銅管に, 地下水あるいは地下水を源 水とする上水を用いた場合に多く経験される。I 型孔食 が発生した銅管内面は塩基性炭酸銅からなる緑青色又 ケールにて全面が覆われ, 同化合物によるマウンドが散 見される。そして，その下部にて孔食が進行し，使用か ら 8 ケ月という短期間で $0.7 \mathrm{~mm}$ 程度の肉厚の銅管が漏洩 に至ることもある。一般に地下水では水中の遊離炭酸が 多くなること, また, 前述のように I 型孔食が軟質銅管 に多いことから銅管の軟化処理の際に生成するカーボ ン皮膜に着目し, 両要因と孔食発生有無との関係を調査 した。なお，カーボン皮膜は，銅管を引き抜き加工して 残存した抽伸油が，軟化処理時の加熱により熱分解して 生成したものである ${ }^{3)}$ 。調査結果に従えば，I 型孔食は 水中の遊離炭酸の影響を強く受けることが確認されて おり, $15 \mathrm{mg} / \mathrm{L}$ 以上の遊離炭酸で発生しやすいことが明ら かとなっている ${ }^{4)}$. 一方，カーボン皮膜の影響について は, 管内平均残留カーボン量（カーボン皮膜を定量化し たもの）と I 型孔食発生との関係が孔食発生個所でのフ イールド試験により調査され, 残留カーボン量が $5 \mathrm{mg} /$ $\mathrm{m}^{2}$ を超えると I 型孔食が発生するとしている ${ }^{4)}$. 以上の 結果から，I 型孔食対策としてこれらの知見が広められ るとともに, 残留カーボン量を $5 \mathrm{mg} / \mathrm{m}^{2}$ 以下とした対策材 が開発され，その適用によって I 型孔食抑制に効果が得 られている。そして，青水対策として有効であった STC 銅管も I 型孔食抑制は可能であり ${ }^{5)}$ ，さらに，給湯器用 熱交換器銅管にも同様に発生する I 型孔食には, 熱交換 器を製造した後の銅管内面に STC 銅管と同様の純 Sn 被 覆処理を施すことにより, I 型孔食発生地域においても 長期にわたり良好な使用実績を収めている ${ }^{6)}$.

（2）ＩI 型孔食

II 型孔食は密閉型貯湯槽を用いた循環配管部で多く 発生し, 後述の潰食に次いで多発している. 外観的には, 局所的に塩基性硫酸銅からなるマウンドが形成され，そ の下部にて孔食が進行することを特徵とする. 水質の特 徵としては, 重炭酸イオンに比較して硫酸イオンが多い こと ${ }^{7)}$ に加え, 給湯水の滅菌用に添加された塩素（塩化
物イオンではない）の影響が大きいとされ，給湯水中の 残留塩素により自然電極電位が上昇し， II 型孔食の孔食 発生電位に早期に到達することが報告されている ${ }^{8)}$ 。ま た，流速の影響も指摘され， II 型孔食発生に対して硫酸 イオン/重炭酸イオン（アニオン）比，残留塩素ならび に流速の影響が調査され，II 型孔食は，アニオン比と残 留塩素との相乗作用によって，低流速ほど発生の可能性 が高まることが示されている ${ }^{9)}$. 対策としては塩素投入 量を減らすことが有効であり，給湯水中の残留塩素濃度 を $0.2 \mathrm{mg} / \mathrm{L}$ 以下とすることでII 型孔食の発生は抑制でき， また，同孔食が既に発生していた場合にも進行が停止す るとの報告がなされている ${ }^{9), 10)}$. 材料的には STC 銅管の 適用が有効であり, また, 設備的な対策については, 後 述のように, 開放式脱気装置が有効策と成り得る. なお, 建築物衛生法では水温が $55^{\circ} \mathrm{C}$ 未満の場合には未端水栓 において $0.1 \mathrm{mg} / \mathrm{L}$ の残留塩素濃度が義務付けられている ため, 塩素投入量を減らす場合には水温を $55^{\circ} \mathrm{C}$ 以上に高 めることが必要である.

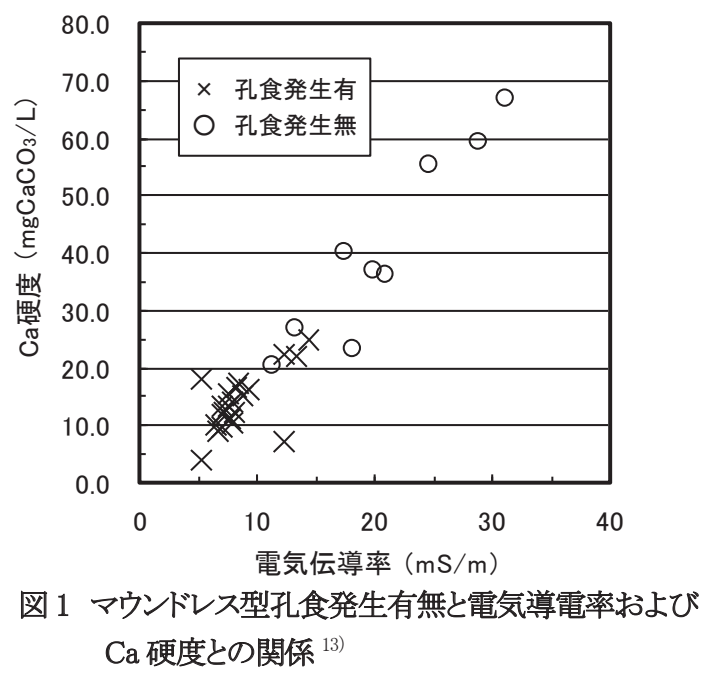

（3）マウンドレス型孔食

マウンドレス型孔食は，一過式給水・給湯配管に銅管を 使用した場合に多く経験されている. 1990 年代初めに北 海道道南の某市にて最初に確認された後，日本全国で見 受けられるようになり，最近では一過式給水・給湯用銅 管の腐食による漏洩事故の中で最多の発生件数となっ ている。そして，銅管の調質には関係なく，軟質銅管， 硬質銅管のいずれにも経験される孔食である．外観的な 特徵は，銅管内面にシリカを主体とする非晶質ガラス状 スケールが全面に生成し，その一部において孔食が進行 するものであり，先に示した I 型孔食や II 型孔食のよう に腐食生成物による顕著なマウンドは観察されない ${ }^{11)}$. 孔食発生要因としては，水中の溶解性シリカの影響を受 けることが指摘され，同濃度が $20 \mathrm{mg} / \mathrm{L}$ を超え，硫酸イ オン/重炭酸イオン (アニオン) 比が 0.5 を上回る場合 にマウンドレス型孔食の発生傾向が強いことが示され た ${ }^{12)}$. しかしながら，最近のマウンドレス型孔食の漏洩 事故状況によれば，両者がこれらを下回る場合にもマウ 
ンドレス型孔食の発生が確認されるようになってきて いる。 そこで, 各水質項目を再度確認して溶解性シリカ が 20mg/L 以下の場合に発生するマウンドレス型孔食に ついて考察したところ, 電気伝導率とカルシウム硬度に より整理可能な結果を得た。すなわち, 図 1 に示すよう に, 電気伝導率が $10 \mathrm{mS} / \mathrm{m}$ 以下でかつ, カルシウム硬度 が $20 \mathrm{mgCaCO}_{3} / \mathrm{L}$ 以下の場合には溶解性シリカが $20 \mathrm{mg} / \mathrm{L}$ 以 下においてもマウンドレス型孔食が発生することを見 出した ${ }^{13)}$.

\section{マウンドレス型孔食の特徵である非晶質のガ}

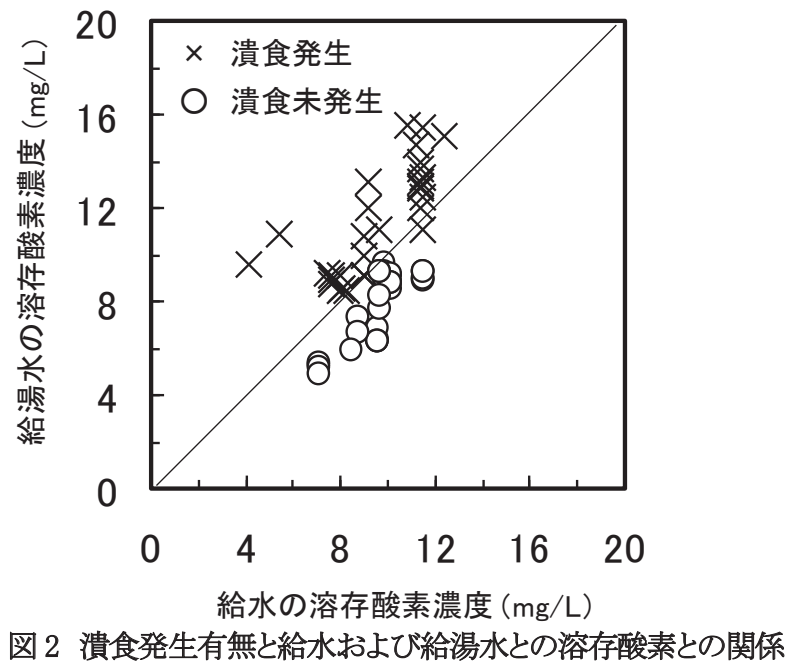

17)

ラス状スケールは, 2 価の金属イオンの存在, すなわち, 銅イオンにより水中の溶解性シリカが反応して析出す る特性を有している ${ }^{14)}$. したがって，対策としては銅イ オンの溶出抑制が可能な STC 銅管および青水対策用に開 発された内面スズ被覆銅管（CL シャット）の適用が有効 となり 12),13)，良好な使用実績を収めている.

\section{$2 \cdot 3$ 潰食}

潰食は, ホテル, 病院等の中央給湯方式の強制循環給 湯システムに採用された銅管にて多く発生する. 同配管 系統における腐食による漏洩事故の半数程度は潰食に よるものである。これまでの調査結果によれば，配管系 統においては還管での漏洩事故が最も多く, 配管サイズ 別には還管で多く用いられる $20 \mathrm{~A} ， 25 \mathrm{~A}$ といった比較的 小口径にて潰食が多発している ${ }^{15)}$. そして, 通湯方向に 対してエルボ継手下流側の銅管の漏洩事故が非常に多 い. 潰食の要因については, 流速の影響が調査され, 潰 食発生に対する臨界流速が示されている ${ }^{1)}$ が, 実態とし ては，同速度以下でも潰食は発生している。一方，上記 の発生傾向にある潰食は, そのほとんどが密閉型貯湯槽 を用いた配管システムにおいて経験されることに着目 し, 図 2 のように, 潰食発生は給湯水中の溶存酸素が給 水中のそれより高い場合に発生しやすいことを明らか とした ${ }^{16)}$, 17). すなわち, 潰食発生個所では給湯水中の 溶存空気は過飽和の状態にあり, 管内の圧力変動によっ て気泡化することが潰食発生に影響するものと仮定し
た.この仮説の検証のため, 種々の試験, 流体力学的解 析を実施し, 過飽和溶存空気は圧力変化に伴いミクロン サイズの微細気泡（ここではマイクロバブルと称する） を発生させること, 発生したマイクロバブルは水流の影 響に従い，潰食が進行する継手部下流において特異的に 乱れて流動することで管壁への衝突頻度が高くなること 示した ${ }^{18)}$. そして，実機相当の通湯試験装置を用いて， 給湯水中の溶存空気が過飽和となる（給湯水の溶存酸素 濃度が給水のそれ以上）条件において潰食を再現させ， 開放式脱気装置により溶存空気を除去することで潰食 が抑制可能となることを報告した ${ }^{19)}$.

開放式脱気装置は, 前述の II 型孔食に加え, 潰食抑制 にも有効である. 同装置は, 給湯配管の往管から分岐し て設置し, 給湯配管の圧力によって容器内に散水して受 水した給湯水を圧力ポンプによって再度配管に戻す機 構を有しており，散水によって腐食因子である過飽和溶 存空気や残留塩素を効率的に除去できる ${ }^{20)}$. 同機構を有 した開放式脱気装置（ナルミ技研製，DS-84L）はフィー ルド的にその効果が確認され, 進行中の腐食も停止でき ることから, 潰食, II 型孔食による漏洩事故防止に有力 な技術と考えている. なお，潰食対策としての材料的な 観点では STC 銅管の適用が有効である ${ }^{6)}$.

\section{$2 \cdot 4$ 疲労割れ $^{21)}$}

疲労割れはそのほとんどが一過式の給湯配管で経験 される。これは給湯使用時と未使用時の温度変化によっ て配管が伸縮を繰り返すことに起因する。そして，いず れの事故例においても割れは管円周方向に横割れとな って発生し, 繰り返し回数 $10^{4}$ 以下で発生する, いわゆ る低サイクル疲労であることが確認されている.疲労割 れを防止するためには, ころがし配管での蛇行の程度, 固定バンドの取付け位置等に留意して応力集中を避ける ことが必要である。

\section{$3 \cdot 1$ 蟻の巣状腐食}

\section{3 空調用・冷凍機用配管}

空調機, 冷凍機の生産が本格した 1970 年代の後半よ り，外観状極めて微小なピンホール状の，そして，その 断面は複雑に入り組んだ形態を有する腐食が多く経験 されるようになり, その形態から蟻の巣状腐食と名付け られた ${ }^{27)}$. その後, 蟻の巣状腐食はギ酸, 酢酸等の直鎖 アルキルカルボン酸を含む湿潤環境における腐食であ ることが明らかとなった ${ }^{23)}$. 塩素系有機溶剤である 1 ・ $1 \cdot 1$ トリクロロエンタンや自己揮発性潤滑油の加水分解 によるカルボン酸の生成が究明され 24), 25)，それぞれの 改善が進められることで蟻の巣状腐食の発生が防止さ れてきた. しかしながら, 環境要因からか, その発生件 数は年々増加傾向にあり, 最近になって無酸素銅による 蟻の巣状腐食への有効性が一部報告されている ${ }^{26)} も の$ の，腐食機構の完全解明といずれの環境においても有効 となる対策材の開発が望まれている.

\section{$3 \cdot 2$ 応力腐食割れ}

銅管は通常の環境では応力腐食割れを生じにくい材 
料であり，応力下での使用によっても問題は生じない. しかしながら，アンモニアを含む環境，あるいは硝酸イ オンや亜硝酸イオンが共存する環境では, 応力腐食割れ が発生する場合がある。応力腐食割れは，管軸方向の縦 割れであること，また，結晶粒界に沿って進行すること が特徴である。銅管の材質としては P 量が 0.015〜 0. $040 \mathrm{mass} \%$ の高りん脱酸銅が多く使用されるが，材料 中の $\mathrm{P}$ 濃度の増加とともにアンモニア等を含む環境では 応力腐食割れの感受性は増加するため ${ }^{27)}$, 環境の改善が 困難な場合には，低りん脱酸銅管（P 量：0.004〜 $0.015 \mathrm{mass} \%$ ） あるいは無酸素銅管の使用を推奨する.

\section{$3 \cdot 3$ 孔食}

冷温水空調システムにおける銅管の孔食は, 開放系蓄 熱槽を使用した空調システムであるエアハンドリング ユニットやファンコイルユニットの熱交換器銅管に散 発的に経験される。 また, 吸収式冷凍機やターボ冷凍機 の伝熱管にも同様に発生することもある。これらにおい ては防食やスケール対策のために各種薬剤が添加され ることがあり (以後, 水処理と称する), 水処理の有無 により発生する孔食の特徵も異なってくる。ここでは, 冷温水空調システムにおける銅管の孔食を, 水処理の有 無により区別して示す.

\section{(1) 水処理無の場合の孔食の特徵 ${ }^{28}$}

水処理無の場合に経験される孔食は，長期間の安定使用 の後, 機器の老朽化にあわせて熱交換器を取り換えた際 に発生することがあり，非常に短期間の使用にて孔食が 進行して漏洩に至る傾向が強い。孔食が発生した銅管の 内面は全面が緑青色スケールで覆われ，局所的に同色の マウンドが散見されてその下部で孔食が進行する.腐食 生成物としては塩基性炭酸銅や亜酸化銅が検出され, 塩 基性硫酸銅が確認されることもある.また，銅管内面に は黄土色の堆積物が多く観察され，これらは主配管であ る鋼管や亜鉛めっき鋼管からの腐食生成物（亜鉛とケイ 素の化合物であるへミモルファイト，鉄酸化物）と判断 されている. 熱交換器内の循環水は, 補給水である上水 と比較して $\mathrm{pH}$ が 8〜9 と若干高く, 酸消費量 $(\mathrm{pH} 4.8)$ も

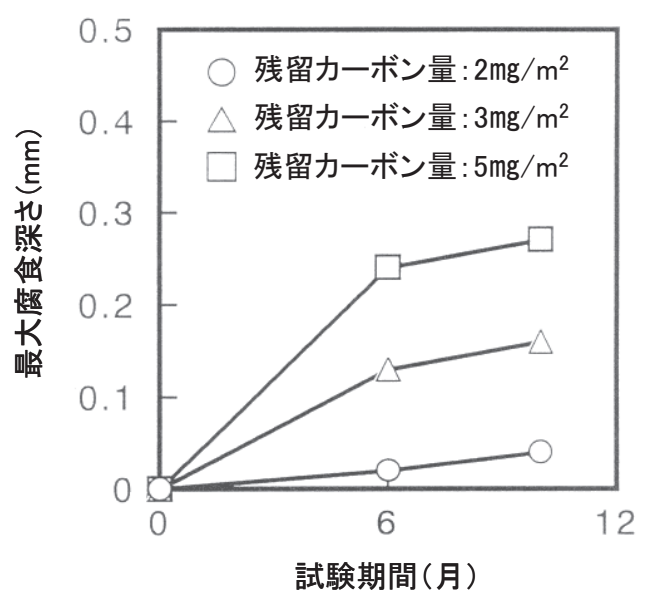

図 3 孔食発生に及ぼす残留カーボン量の影響 ${ }^{28)}$

100 数 $100 \mathrm{mgCaCO}_{3} / \mathrm{L}$ と高い. そして, 上述の腐食生成物
が水中微粒子となって水中に浮遊するため蒸発残留物 も非常に多いことが特徵である。一方，材料側の腐食要 因量と水中微粒子との関係が孔食を発生させた施設で のフィールド試験によって検証された. 図 3 に腐食深さ の経時変化を示す.試験結果に従えば，残留カーボン量 の増加に伴い孔食の進行が顕著となることが確認され た.また，水中微粒子の影響を調査した試験では，フィ ルターによって水中微粒子を除去することで腐食の進 行が遅延される結果が得られ，主配管の腐食生成物の影 響が明らかとされた。

\section{(2) 水処理有の場合の孔食の特徴}

各種薬品を用いた水処理は，運用開始時から実施され る場合と，主配管である鋼管や亜鉛めっき鋼管の腐食に 伴い実施される場合の 2 通りがあり，後者の場合が多い とされている.そして，孔食の発生は，先に示した水処 理無の場合と同様，伝熱管を取替えた後に短期間の使用 によって漏洩に至ることを特徵としている。同環境にて 発生する孔食は局所的に生成した緑青色の斑点状の腐 食生成物の下部で進行する。これまでに，ホスホン酸系 化合物を添加した場合について，孔食発生に及ぼす添加 条件や水質の影響が調査され，ホスホン酸系化合物，硫 酸亜鉛ならびにベンゾトリアゾールの三者共存下のみ で孔食が発生すること，硫酸イオンの増量とともに，ま た，低 $\mathrm{pH}$ ほど発生傾向が増大すること，カルシウム硬 度の増大により低 $\mathrm{pH}$ でも孔食が抑制されること等が明 らかとされた ${ }^{29)}$ 31) 。一方，前述のごとく，水処理実施 時の孔食の発生は，水処理を開始した直後に伝熱管を取 替えることで多く経験されることから，水処理無の場合 と同様，長年の使用で変質した使用水と各種薬品添加の 影響だけでなく，伝熱管に用いた銅管のカーボン皮膜の 影響を強く受けるものと考えられた。

\section{(3) 残留カーボン量の影響と対策材の効果}

著者らの調査では，水処理有無によらず，残留カーボ ン量の増加とともに自然電極電位が貴となる傾向を得 ており，この傾向を示した銅管において孔食発生を確認 している.すなわち, 孔食抑制については残留カーボン を除去することが有効であり，これまでの試験結果によ れば, 残留カーボン量を $2 \mathrm{mg} / \mathrm{m}^{2}$ 以下とすることで電位の 貴化が抑制されて良好な耐食性が得られることを検証 している ${ }^{28)}$ ，32)。 これらの観点から，特殊な酸洗浄 ${ }^{33)}$ あるいは熱処理条件の工夫によって残留カーボン量を $2 \mathrm{mg} / \mathrm{m}^{2}$ 以下とした耐食性銅管（CLT）を開発し，その性 能を孔食による漏洩が生じた実機冷温水空調システム でのフィールド的に調査して良好な耐食性を確認した 34).

\section{$4 \cdot 1$ 銅合金の種類}

\section{4 海水使用の熱交換器}

銅合金の種類と特性を表 2 に示寸.伝熱性能の良い銅は局 部腐食を受ける35)ので使用できず,銅合金に絞られることにな り,一番基本的なアルミニウム黄銅,污染水腐食対策用の $\mathrm{AP}$ ブ ロンズ,高価なキュプロニッケル(コストパフォーマンスから はアルミニム黄銅で充分である),これらに鉄粉を含んだ塗料を 塗布し污染水腐食やエロージョン・コロージョンに完全な耐食性 
を有する $\mathrm{APF}$,初期皮膜としての鉄皮膜を化学反応で付着させ たフェロコがある.さらに、これらの管とチタン管との 2 重管 があり,任意の管を内管にできるので,内面腐食対策では内面 にチタン管を,アンモニアアタック対策では内面に銅合金を, 大型付着生物対策では内面に $10 \%$ キュプロニッケル管を用い る.

\section{$4 \cdot 2$ アルミニウム黄銅とキュプロニッケルの耐食性と鉄} 注入

佐藤 36 は,アルミニウム黄銅とキュプロニッケルの皮膜,即 ち,何か表面にくっついたものが耐食性の根源であり、皮膜と 皮膜のないところとの間で電位差がない付着物であるとした.

付着すると悪い付着物としては電位差の大きい硫化物と電 位は僅かにノーブルだが腐食の駆動力としては不足ではある 37)が,剥離しやすいマンガンに富む付着物が知られている.
で良好な保護皮膜となる.しかし,鉄注入によって形成された 保護皮膜もたえず剥離し続ける41)ので,鉄注入を継続すること が必要であるとともに,鉄皮膜の耐せんだん力には限界があ る.

標準的な管入口部の場合, $25.4 \mathrm{~mm} \phi, 1.245 \mathrm{mmt}$ のアルブラ ックでは,管内流速 $3.8 \mathrm{~m} / \mathrm{s}$ には耐えられる ${ }^{42)}$.

固型物閉塞によるエロージョン・コロージョンに対しては 管断面積の半分までの閉塞に耐えられる ${ }^{43)}$.

漂砂に対しては、ある限度を超えると耐えられなくなる ${ }^{44)}$. 污染水に対しては,予め良好な鉄皮膜を育成しておけば,短 期間の来襲には耐えられる 45).

\section{5 大型付着生物付着防止用防污板}

銅合金の板をコンクリートにはケミカルアンカー46)で鉄管に は磁石で貼付47)すれば,表面から自然の腐食によって溶解して いき,溶解速度の低下は普通みられず,銅合金の存在する限り，

表 2 銅合金の種類と特性

\begin{tabular}{|c|c|c|c|c|c|c|c|}
\hline \multirow{2}{*}{$\begin{array}{l}\text { 材質 } \\
\text { 商品名 }\end{array}$} & \multicolumn{3}{|c|}{ アルミニウム黄銅 } & \multirow{2}{*}{$\begin{array}{l}10 \% \text { キュプロ } \\
\text { ニッケル }\end{array}$} & \multirow{2}{*}{$\begin{array}{l}30 \% \text { キュプロ } \\
\text { ニッケル }\end{array}$} & \multirow{2}{*}{$\begin{array}{l}\text { 高 } \mathrm{Fe} \text { 高 } \mathrm{Mn} \text { キュ } \\
\text { プロニッケル }\end{array}$} & \multirow{2}{*}{$\begin{array}{l}\mathrm{AP2} \\
\mathrm{AP} \text { ブロンズ }\end{array}$} \\
\hline & アルブラック & アルミブラス & エバーブラス & & & & \\
\hline メーカ & UACJ 銅管 & 神鋼 & 古河 & & & & UACJ 銅管 \\
\hline JIS & \multicolumn{6}{|c|}{ H3300 } & \\
\hline 合金番号 & C6871 & $\mathrm{C} 6872$ & C6870 & $\mathrm{C} 7060$ & $\mathrm{C} 7150$ & $\mathrm{C} 7164$ & \\
\hline 旧材質記号 & BsTF2 & BsTF3 & BsTF4 & CNTF1 & CNTF3 & & \\
\hline $\mathrm{Cu}(\%)$ & \multicolumn{3}{|c|}{$76.0 \sim 79.0$} & \multicolumn{2}{|c|}{$\mathrm{Cu}+\mathrm{Ni}+\mathrm{Fe}+\mathrm{Mn} 99.5$ 以上 } & 同左 & $\mathrm{R}$ \\
\hline $\mathrm{Sn}(\%)$ & & & & & & & $7.0 \sim 9.0$ \\
\hline $\mathrm{Si}(\%)$ & $0.2 \sim 0.5$ & & & & & & $0.1 \sim 0.3$ \\
\hline $\mathrm{Al}(\%)$ & \multicolumn{3}{|c|}{$1.8 \sim 2.5$} & & & & \\
\hline $\mathrm{Ni}(\%)$ & & $0.2 \sim 1.0$ & & $9.0 \sim 11.0$ & $29.0 \sim 32.0$ & $29.0 \sim 32.0$ & \\
\hline $\mathrm{Pb}(\%)$ & \multicolumn{6}{|c|}{0.05 以下 } & 0.07 以下 \\
\hline $\mathrm{Fe}(\%)$ & \multicolumn{3}{|c|}{0.05 以下 } & $1.0 \sim 1.8$ & $0.40 \sim 1.0$ & $1.7 \sim 2.3$ & \\
\hline $\mathrm{Zn}(\%)$ & \multicolumn{3}{|c|}{$\mathrm{R}$} & 0.5 以下 & 0.5 以下 & 0.5 以下 & \\
\hline $\operatorname{Mn}(\%)$ & & & & $0.2 \sim 1.0$ & $0.2 \sim 1.0$ & $1.5 \sim 2.5$ & \\
\hline $\mathrm{As}(\%)$ & \multicolumn{3}{|c|}{$0.02 \sim 0.06$} & & & & \\
\hline 密度 $\mathrm{g} / \mathrm{cm} 3$ & \multicolumn{3}{|c|}{8.33} & 8.94 & 8.94 & & 8.8 \\
\hline 熱伝導率 & \multicolumn{3}{|c|}{100} & 46 & 29 & & 63 \\
\hline
\end{tabular}

熱伝導率: $\mathrm{W} /(\mathrm{m} \cdot \mathrm{K})$

清浄海水の場合,アルミニウム黄銅の腐食は鉄注入ありでも, 鉄注入なしでも,塩素あり,なしにかかわらず,付着物量の増加 とともに,腐食速度は低下し, $18 \mathrm{~g} / \mathrm{m}^{2}$ で $20 \mu \mathrm{m} / \mathrm{y}$ に低下する ${ }^{38)}$. 清浄海水下,塩素なしにおける海水通水下の銅合金は生物皮 膜によって完全に全面腐食が防止される 39).アルミニウム黄 銅管に清浄海水を $2 \mathrm{~m} / \mathrm{s}$ で通水した場合の腐食量は,通水初期 3 力月で $0.025 \mathrm{~mm}$ の腐食を示寸が,生物皮膜が成長した 3 力 月以降は腐食の進行はみられなかった ${ }^{39)}$.

しかし,生物皮膜の成長や損傷後の修復が阻害される条件, 即ち,塩素等のバイオサイドやスポンジボール洗浄等の機械的 掃除が実施される場合には, 銅合金の防食のためには,生物皮 膜の損傷の程度に応じた生物皮膜の補強が必要となる.補強法 としては,効果があり,かつ容易な方法として鉄注入によるい わゆる鉄皮膜育成法があり, 分極抵抗 $2 \times 10^{4} \Omega \cdot \mathrm{cm}^{2}$ 以上 ${ }^{40)}$
大型付着生物を完全に防止できる。

\section{6 細菌対策用資材}

\section{$6 \cdot 1$ 銅ならびに銅合金との接触効果}

昔はドアノップは黄金色に輝いていた,銅ならびに銅合金 には殺菌作用がみられる 48 .

\section{$6 \cdot 2$ 病院の病原菌対策用資材}

銅溶射のシンク 48 , 銅製グリップの抗菌ポールペン 50$),$ 銅 の床等がある.

\section{$6 \cdot 3$ 魚病対策用資材}

水路に銅䋊維を投入したりする 48 .

\section{$6 \cdot 4$ 腐敗対策用資材}

貯めた雨水に黄銅䋊維を投入する ${ }^{48)}$.

\section{$6 \cdot 5$ 生物皮膜用資材}

流しのバスケットや三角コーナを銅製に替えると生物皮 
膜がほとんど付着しない ${ }^{48)}$.

\section{$6 \cdot 6$ 微小藻類対策用資材}

銅は下水処理場の沈殿池 ${ }^{49)}$,越流堰 ${ }^{49)}$,人工の川 や噴水 ${ }^{48)}$ の藻の発生を防止できる.

\section{7 おわりに}

多くの特長を有する銅・銅合金は使用環境と材 料の特質を理解すれば長期管安定使用が可能とな る.本報が需要家の皆様の参考となれば幸いであ る。

\section{参考文献}

1) S. Yamauchi and S. Sato, " Corrosion of copper tubes in fresh water" Boshoku Gijutsu, Vol.30, No. 8, pp. 469-477. (1981)

2) Y. Yamada, J. Ito, T.Atsumi and K. Nagata, "Performance of tin coated copper tube against cuprosolvency problem "blue water" in the East of Hokkaido" Journal of the JCBRA, Vol.34, pp. 107-112. (1995)

3) T. Atsumi, H. Morita and S.Miyoshi, "Effect of hydrogen gas on the thermal behavior of lubricant oil remaining in copper tubes during annling" Sumitomo Light Metal Technical Reports, Vo1.46, No. 1, pp. 6-16. (2005)

4) Y. Yamada, K. Kawano, S. Suzuki, T. Atsumi and K. Sawa, "Pitting corrosion of copper tubes in we11 water" Sumitomo Light Metal Technical Reports, Vol.40, No.1, pp.53-60. (1999)

5) S. Suzuki, Y. Yamada, T.Atsumi, K. Kawano and 0. Toriyama, "Performance of tin coated copper tube in the water service system in which the copper plumbing tubes have been suffering from corrosion" Journal of the JCBRA, Vol.39, No.1, pp. 261-267. (2000)

6) S. Suzuki, Y. Yamada, K. Kawano and 0. Toriyama, "STC(Super tin coat)copper tube with high corrosion resistance" Zairyo-to-Kankyo, Vo1.57, No. 6, pp. 269-273. (2008)

7) E. Mattsson and A.M.Frendriksson, "Pitting corrosion in copper tubes-cause of corrosion and counter-measures" Brit. Corros. J, Vol.3, pp246-257. (1968)

8) H. Baba, T.Kodama, T.Fujii, Y. Hisamatsu and Y. Ishikawa, "Measurements of pitting potential of copper tubes in hot water" Boshoku Gijutsu, Vol. 30, No. 2, pp. 113-118. (1981)

9) T. Hamamoto, M. Kumagai, K. Kawano and S. Yamauchi, "Effect of water compositions on the pitting corrosion of copper tubes in hot water service" Sumitomo Light Metal Technical Reports, Vo1.28, No.2, pp.70-75. (1987)

10) K. Kasahara, S. Komukai and T.Fujiwara, "Prevention of pitting corrosion of copper tubes in central hot water supply systems by UV photochemical decomposition of residual chlorine” Boshoku Gijutsu, Vo1.37, No.7, pp. 423-431. (1988)

11) Y. Yamada and T.Atsumi, "Moundless pitting corrosion of copper cold and hot water pipes" Zairyo-to-Kankyo, Vo1.46, No.3, pp.134-135. (1997)

12) Y. Yamada, O.Seri and M. Arakawa, "Study on moundless pitting corrosion of copper tubes and prevention of its occurrence" Journal of the JRICu, Vo1.42, No.1, pp. 271-274. (2003)

13) S. Suzuki, K. Kanamori and K. Kawano,

"Moundless pitting corrosion and its prevention in copper tubes" Sumitomo Light Metal Technical Reports, Vol.52, No.1, pp.45-50. (2001)

14) T. Kodama, "Characteristics of fresh water" Proceedings of the $1^{\text {st }}$ Technical Seminar on the Japan Society of Corrosion Engineering, pp. 1-10. (1992)

15) Y. Yamada, K. Kawano and T. Atsumi, "Erosion corrosion and its countermeasure of copper tube in hot water forced circulating system" Journal of the JCBRA, Vo1.36, No.1, pp.154-160. (1997) 16) K. Kawano, Y. Yamada and S. Nakano, "Dissolved oxygen behavior in hot-water in hot-water forced circulating system" Journal of the JRICu, Vo1.46, No. 1, pp.212-215. (2007)

17) T. Yamate, Y. Okubo, Y.Omote, K. Kawano. and Y. Yamada, "Study on the behavior of dissolved gas and prevention of erosion corrosion in copper pipes in the circulation type hot water supply piping system of building equipment" Sumitomo Light Metal Technical Reports, Vol.50, No.1, pp. 6-11. (2009)

18) S. Suzuki, Y. Yamada and K. Kawano, "Effects of bubble behavior on erosion corrosion of copper tubes in hot-water supply system" Zairyo-to-Kankyo, Vo1.58, No.3, pp.99-104. (2009)

19) K. Kawano and S. Suzuki, "Erosion corrosion and its prevention of copper tube in hot-water circulating system" Sumitomo Light Metal Technical Reports, Vol.54, No.1, pp.51-56. (2013)

20) Japanese Patent No. 5294476.

21) K. Kawano, Y. Yamada and K. Nagata, "Crack of copper tubes in hot-water supply system" Zairyo-to-Kankyo, Vo1.43, No.7, pp.396-398. (1994)

22) S. Yamauchi, K. Nagata, S. Sato and M. Shimoni, "Peculiar type of corrosion- "formicary corrosion" -of copper tube” Journal of the JCBRA, Vo1.22, pp. 132-140. (1983)

23) T. Notoya, T. Hamamoto and K. Kawano, "Formicary corrosion in copper tubes in wet atmospheric conditions" Sumitomo Light Meta1 Technical Reports, Vo1.30, No.3, pp.123-128. 
(1989)

24) T. Hamamoto and M. Imai, "Organic chlorinated solvent and formicary corrosion in copper tube" Journal of the JCBRA, Vol.30, pp.92-98. (1991) 25) T. Takahashi, Y. Shiraishi, Y. Saito, H. Ogawa and M. Watanabe, "The Influence of lubricant oils on formicary corrosion in copper tubes" Journal of the JCBRA, Vo1.31, pp. 143-150. (1992) 26) K. Miya, "Corrosion resistance of oxygen free copper to ant nest corrosion" Zairyo-to-Kankyo, Vo1.61, No.11, pp.438-442. (2012)

27) D. H. Thompson and A.W. Tracy, "Influence of composition on stress ${ }^{-}$corrosion cracking of some copper-base alloys" Transaction AIME, Vo1. 185, pp.100. (1949)

28) Y. Yamada, T.Atsumi, A. Mori, R. Hatanaka and N. Nakano, "Pitting corrosion of copper tubes in the air conditioning system having the open heat storage water tank" Sumitomo Light Metal Technical Reports, Vol.39, No.1, pp.79-84. (1998)

29) Y. Yamada, O. Seri, K. Tagashira and K. Nagata, "Pitting corrosion of copper in aqueous solutions containing phosphonic acid as an inhibitor" Zairyo-to-Kankyo, Vol.42, No.9, 558-563. (1993)

30) Y. Yamada, O. Seri, K. Tagashira and K. Nagata,

"The Effect of pH on the pitting corrosion of opper in a phosphonic acid solution, Hyoumen Gijutsu, Vol.44, No.2, 172-175. (1993)

31) Y. Yamada, 0. Seri, K. Tagashira and K. Nagata,

"Effect of Ca hardness on the pitting corrosion of opper in a phosphonic acid solution and the monitoring of pitting corrosion" , Hyoumen Gijutsu, Vo1.44, No.4, 353-356. (1993)

32) S. Suzuki, K. Kawano, K. Hosoya, K. Takada and N.Hirose, "Corrosion and its prevention of copper coiled tubes in air conditioning system" Proceedings of the $53^{\text {th }}$ Conference on the Japan Institute of Copper, pp.33-34. (2013)

33) Japanese Patent No. 5072059.

34) S. Suzuki and K. Kawano, "Corrosion behavior and its prevention of copper tube in air conditioning system using hot and cold water" Sumitomo Light Metal Technical Reports, Vol.53, No. 1, pp. 99-104. (2012)

35) A. Kawabe, " Biofoulingcontroltechnologies" , pp. 2 31-249. Marine Biofouling Control Committee, The Electrochemical Society of Japan(2001)

36) S. Sato, " Optimization of anti-corrosion and antibiofouling method for alminum brass condenser tubes", The Thermal and Nuclear Power, Vo1. 37, No. 7, pp. 741-763. (1986)

37) N. Yamamoto and A. Kawabe, ” Development of artificial formation method of manganese rich deposit" Journal of the JRICu, Vol.47, No. 1, pp. 261265. (2008)

38) K. Nagata, A. Ogiso and S. Sato," Development of albrac condenser tubes with artificial protective film-APF" The Thermal and Nuclear Power, Vol.32, No. 6, pp. 577-588. (1981)

39) A. Kawabe, " Review on development of biofouling control ' 99" The Thermal and Nuclear Power, Vol. 51, No. 3, pp. 286-300. (2000)

40) JIS H 0530

41) A. Kawabe, H. Ikusima, S. Ii jima, S. sato, K. Nagata and S. Yamauchi," Optimum method of protective initial film formation on alminium brass condenser tubes" The Thermal and Nuclear Power, Vol.29, No. 7, pp. 679-695. (1978)

42) S. Sato and T. Nosetani, " Allowable water velocity and cleanliness factor of aluminium brass condenser tube with ferrous ion addition into sea water" Sumitomo Light Metal Technical Reports, Vol. 11, No. 4, pp. 271-280. (1970)

43) A. Kawabe, "Corrosion and anti-corrosion of condenser tubes" pp. 2, Chugoku Branch, The Thermal and Nuclear Power Engineering Society (1988)

44) S. Sato and K. Nagata, "Factors affecting corrosion and fouling of condenser tubes of copper alloys and titanium in sea water" The Thermal and Nuclear Power, Vol.29, No. 7, pp. 597-607. (1978)

45) H. Ando, Y. Yamaguchi, K. Onda, S. Sato and A. Ogiso,

" Importance of initial film on the anti-corrosion of condensertubes" The Thermal and Nuclear Power, Vol. Power, Vo1.23, No. 2, pp. 207-217. (1972)

46) T. Nonaka, T. Yanagi hara, H. YokouchiandA. Kawabe, , ” Prevention technique for marine biological fouling employing metal panels" Annual Meeting of the Electrochemical Society of Japan, Abstr., pp. 21. 2001 47) S. Mizoguchi," A Study on metalic materials for anti-fouling performance" Annual Meeting of the Electrochemical Society of Japan, Abstr. , pp. 94. 1998 48) Nippon Sinndo Kyokai Sindohin Deta-book Hensyuiinkai, “Sindohinn deta-book” pp. 172-176 (2009) Nippon Sindo Kyokai

49) Doban niyoru Gesuisyorizyo no Bosotaisaku, Copper, No. 27, pp. 34 (1994) 